\title{
Internal audit role on information asymmetry and real earnings management
}

\author{
Jasman ${ }^{1}$, Muhammad Nuryatno Amin ${ }^{2}$ \\ ${ }^{1}$ Faculty of Economics and Business, IKPIA Perbanas, Jakarta, Indonesia \\ ${ }^{2}$ Faculty of Economics and Business, Universitas Trisakti, Jakarta, Indonesia \\ e-mail: ${ }^{1}$ jasman@perbanas.id
}

\section{A R T I K E L I N F O}

Article history:

Available online

Keywords:

information asymmetry, quality of

internal audit, real earnings

managemen

\section{A B S T R A C T}

This study aims to investigate the effect of information asymmetry toward real earnings management which are moderated by quality of internal audit function. The research design is quantitative method using secondary data. The sample used in this study consisted of 116 manufacturing companies which are listed on Indonesian Stock Exchanges. Earnings management through real activities manipulation which is also called real earnings management is proxied with three patterns: cash flow from operation (CFO), production costs, and discretionary expenses. The result shows that information asymmetry has a positif and significant effect toward real earnings management in the pattern of cash flow from operation and production costs. Meanwhile, information asymmetry has no effect toward real earnings management in the pattern of discretionary expenses. This research also found that quality of internal audit has significant effect in mitigating the effect of information asymmetry toward real earnings management in the pattern of cash flow from operation and production costs. Internal audit quality does not play an important role in alleviating real earnings management in discretionary expenses pattern.

\begin{abstract}
A B S T R A K
Penelitian ini bertujuan untuk menguji pengaruh asimentri informasi terhadap manajemen laba riel yang dimoderasi oleh peran kualitas internal audit. Rancangan penelitian adalah metoda kuantitatif dengan menggunakan data sekunder. Sampel yang digunakan terdiri dari 116 perusahaan manufaktur yang terdaftar di Bursa Efek Indonesia. Manajemen laba melalui manipulasi aktivitas riel yang juga dinamakan manajemen laba riel diproksikan dengan tiga pole yaitu arus kas operasi, biaya produksi, dan beban diskresioner. Hasil penelitian menunjukkan bahwa asimetri informasi memiliki pengaruh signifikan positif terhadap manajemen laba riel pada pola arus kas operasi dan biaya produksi. Sementara itu, asimetri informasi tidak memiliki pengaruh terhadap manajemen laba riel pada pola beban diskresioner. Penelitian ini juga menemukan bahwa kualitas internal audit berpengaruh signifikan di dalam mengurangi pengaruh asimetri informasi terhadap manajemen laba riel pada pola arus kas operasi dan biaya produksi. Kualitas internal audit tidak berperan di dalam mengurangi pengaruh asimetri informasi terhadap manajemen laba riel pada pola beban diskresioner.
\end{abstract}

\section{Introduction}

Earnings management is an option taken by management in accounting policies used to achieve a particular goal (Scott 2015). Earnings management is undertaken in various ways such as taking a bath, income minimization, income maximization, and income smoothing (Kassamany et al. 2017). Two common types of earnings management are accrual earnings management and earnings management through real activities manipulation which is also called real earnings management.

Most of the researches in earnings management has focused on accrual-based earnings management (Chae et al. 2016; Jafarpour and Gilaniniay 2013; Kalgo et al. 2015; Zang 2012; Qi et al. 2014). Real earnings management is conducted based on real activities manipulated by management interest to mislead shareholders in order to believe that predetermined earnings target has been achieved. Real earnings management is commonly undertaken through three patterns: cashflow from operation (CFO), production costs, and discretionary expenses (Roychowdhury 2006). The researches have examined whether exposure media and corporate actions such as dividen polity, IPO affect accruals earnings management. Meanwhile, there is a limited research of earnings 
management using real activities in manipulating earnings (Kassamany et al. 2017; Eldenburg et al. 2011; Ge and Kim 2014; Aslani et al. 2014; Rizvi and Khan 2015).

Information asymmetry occurs in the availability of information where one party has more knowledge than the other. A higher degree of asymmetric information leads to a more difficult for shareholders to monitor managers; therefore, managers may be better able to use their discretion over earnings (Jiraporn et al. 2008). Therefore, to improve the quality of profit, it is important to increase the transparency of information (Dai et al. 2013). Some researches have proved that transparency can be improved with the level of disclosure to reduce information problems (Healy and Palepu 2001). The more transparent reporting can reduce the effort of earnings management (Hunton et al. 2006). In addition, firms with larger disclosures are less likely to face information problems or lead to less earnings management practices (Jo and Kim 2007).

As opposed to the previous findings, Lang and Lundholm (2000) provide empirical evidence that managers are also possible to use certain disclosure strategies to mitigate transparency and hype their firm's stocks (Lang and Lundholm 2000). Therefore, there are information intermediaries (financial analysts, underwriter, external auditors, etc) which influence the effectiveness of disclosure and accordingly mitigate earnings management (Jo and Kim 2007). In fact, inside the internal company there is actually a profession that serves as a supervisor of operations and finance which is called internal auditors. Based on its function, internal auditors are believed to play an important role in moderating the influence of information asymmetry toward real earnings management.

Preparation of fraudulent financial statements would be less likely to occur when controls in the enterprise were effectively implemented (Weng et al. 2015). The effective internal control would go through the function of Internal Audit quality (Ma'ayan and Carmeli 2016). Internal auditors play an important role in mitigating agressive accounting behaviour of management; hence, reliable internal auditor is expected to take action on anticipating every fraudulent action which could occur in the future (Prawitt et al. 2009). Ege (2015) comfirms that high quality of internal auditor is more likely mitigate management misconduct as compared to low quality of internal auditor. Thus, high-quality internal audits act as effective prevention for earnings management, because management reputation will be damaged and assessments of the firm will be reduced if errors in financial statements are detected and revealed. Gramling and Hermanson (2009) says that the quality of internal audit is based on what inputs and processes are used to produce quality performance products, in other words, using the average experience of audit professionals, certification owned by professional auditors, and training provided to the internal auditors.

Based on the previous discussion of the research gap, the motivation of this study is to examine the role of internal audit quality toward the influence of information asymmetry on real earnings management. Research related to the role of internal audit quality toward real earnings management is very limited. Significance of this research is to contribute to stakeholders on how internal audit quality play an important role in alleviating real earnings management. Next section of this paper discusses literature review and hypothesis development, research method, result and discussion, and conclusion.

\section{Literature Review}

\section{Information Asymmetry and Real Earnings Management}

Jensen and Meckling (1976) define agency theory as a contract between shareholders as principal and management as agents. Management is given the authority in decision making for the interest of shareholders. However, if both parties had different interests, it was not impossible that the agent behaves inappropriately with the interests of the shareholders. Shareholders may restrict agents' deviant activities by increasing control tools over management activities such as the quality of internal auditors.

Two main motivations which managers undertake earnings management, namely opportunistic goals and signaling to investors (Scott 2015). Opportunistic goals may be detrimental to users of financial statements because the information submitted by management becomes inaccurate and also does not reflect the fundamental value of the company. This opportunistic attitude is perceived as a fraudulent attitude of corporate management implied in its financial statements when facing an intertemporal choice that is a condition that forces the executive to use certain decisions in reporting a favorable performance for himself in the face of certain situations.

Signaling is likely to bring a good impact for users of financial statements. Interesting financial performance information would signal the owner that his or her investment is profitable. Therefore, managers try to inform opportunities that can be achieved by the company in the future. An et al. (2011) argue that signaling theory is concerned with how to address problems arising from information asymmetry in any social settings.

Information asymmetry occurs in the availability of information where one party has more knowledge than the other. High level of information asymmetry causes stakeholders to have inadequate resources or access to relevant information to monitor management activities in the practice of earnings management (Jiraporn et al. 2008). Therefore, to improve the quality of profit, it is important to increase the transparency of information (Dai 
et al. 2013). The more transparent reporting can reduce the effort of earnings management (Hunton et al. 2006). Other empirical evidence suggests that firms with larger disclosures are less likely to face information problems or lead to less earnings management practices (Jo and Kim 2007). The proposed hypothesis, thus, are the following: Hypothesis $1\left(\mathrm{H}_{1}\right)$ : Information asymmetry has a positive effect toward real earnings management

\section{Internal Audit Quality, Information Asymmetry, and Real Earnings Management}

Information Asymmetry refers to the information imbalance between the principal as the owner and the agent as management. The problem of numerous irregularities, such as the preparation of fraudulent financial statements, would not occur if the controls in the enterprise were effectively implemented. Therefore, internal control system needs to be improved through the function of internal audit departement hereinafter referred to as Effective Internal Audit. The quality of internal auditor services in the internal audit process is determined by the internal auditor's ability to apply the Professional Standards of Internal Audit. Internal auditors help to make company operations more efficient and effective in increasing shareholder value (Fadzil et al. 2005).

Internal auditors are referred to as management partners as well as supervisors who are expected to provide their expertise to help the organization achieve its goals. Fadzil et al. (2005) in their study found that managing the internal audit department, internal auditor professionalism and objectivity had a significant effect on risk assessment of the internal control system. In other words, the function of internal auditors, among others, is to improve the effectiveness of internal controls so that it can lead to the achievement of objectives that have been set.

Several studies have proven the association between internal control and information asymmetry. ElMahdy and Park (2014) in their study of companies in U.S found that internal control weaknesses increase information asymmetry. Firms with internal control weakness are high enough to cause less accurate analyst forecasts and improve the bias (Xu and Tang 2015; Weng et al. 2015). Internal control gratitude is also associated with lower quality accruals. In general, the higher the degree of weakness of internal control the higher the likelihood of investors becoming information asymmetry (Beneish et al. 2008). Gramling and Hermanson (2009) describe the inputs used in the process to produce quality audit performance products, namely, first, the average audit experience of audit professionals. Second, the nature and type of training for audit professionals and the three levels of audit certification.

Prawitt et al. (2009) demonstrate that companies with higher-quality internal audit function quality are associated with smaller negative abnormal accruals. Ege (2015) shows that reliable internal auditors are expected to take steps to anticipate any possible deviation in the future and as compared to low quality auditors, high quality auditors are more likely to reduce management misconduct. Gramling and Hermanson (2009) argue that the quality of internal audit is seen from what inputs are used and processes. What is used to produce a quality performance product, that is, by using the average audit experience of professional audit, professional level audit certificate, and training for audit professionals Based on the above discussion the following hypothesis is determined.

Hyphotesis $2\left(\mathrm{H}_{2}\right)$ : Internal audit quality mitigates the positive effect of information asymmetry toward real earnings management

\section{Firm Size, Leverage, and Market to Book}

Olsen and Stekelberg (2016) argue that firm size has a negative sign on management misconduct. Also, Dechow and Dichev (2002) confirm that the smaller the firm, the lower accrual quality. In addition, large firms will be more stable and predictable in operation rather than small firms. Thus, firm size has a negative effect on earnings management.

Leverage has a positive relation with management misconduct (Ege 2015). Furthermore, Scott (2015) demonstrates that firms which have high debt-to-equity ratios tend to use accounting methods to increase corporate earnings to fulfill debt covenants. Therefore, leverage ratio has a positive effect on real earnings management.

Raoli (2013) denotes that income-increasing earnings management related to an increase in a firm's market value and income-decreasing earnings management related to a decrease in a firm's market value. In addition, Roychowdhury (2006) which investigates eanings management through real activities manipulation found that suspect firm-years with high market-to-book ratio exhibit higher abnormal production costs than other suspect firmyears; in contrast, suspect firm years with high market-to-book ratio exhibit lower abnormal discretionary expenses than other suspect firm-years. Based on the above discussion, market to book value has a positif effect toward real earnings management. 


\section{Research Method}

\section{Sample Selection}

Population of this study is all manufacturing companies listed on the Indonesia Stock Exchange (IDX). The manufacturing sector is chosen because it is the dominant industry with many companies listing in IDX and manufacturing industry has played an important role in contributing Indonesia's economic growth towards employement, exports, and National Gross Domestic which was 20,8\% in 2013 (Nurcahyo and Wibowo 2015). The technique of determining the sample is purposive sampling with criteria: (1) Manufacturing companies listed in IDX during 2013-2015, (2) The Company issued financial statements and other management reports for the period ended December 31, (3) the company published a complete data in the form of Financial Reports and other management reports during 2013-2015. Based on the selected criteria, there are 116 manufacturing companies (348 firm-years of observation) can be analyzed.

\section{Variables and Measurement}

Real earnings managements were measured by using three models developed by Roychowdhury (2006).:

1. Cash flow from operation (CFO) as a linear function of sales and sales changes in one period:

$$
\mathrm{CFO}_{t} / A_{t-1}=\alpha_{0}+\alpha_{1}\left(1 / A_{t-1}\right)+\beta_{1}\left(S_{t} / A_{t-1}\right)+\beta_{2}\left(\Delta S_{t} / A_{t-1}\right)+\varepsilon_{t} .
$$

1. Normal production costs is Prodt $=$ COGSt $+\Delta \mathrm{INVt}+$, using the following regression equation: $\operatorname{PROD}_{t / A_{t-1}}=\alpha_{0}+\alpha_{1}\left(1 / A_{t-1}\right)+\beta_{1}\left(S_{t / A_{i-1}}\right)+\beta_{2}\left(\Delta S_{t} / A_{t-1}\right)+\beta_{3}\left(\Delta S_{i-1} / A_{t-1}\right)+\varepsilon_{t}$

2. Normal discretionary expenses by using the following regression equation

$\operatorname{DISEXP}_{t / A_{t-1}}=\alpha_{0}+\alpha_{1}\left(1 / A_{i-1}\right)+\beta\left(S_{t} / A_{i-1}\right)+\varepsilon_{t}$.

where CFOt $=$ Operating cash flow of company $\mathrm{i}$ in year $\mathrm{t}$; Prodt $=$ Production costs of company $\mathrm{i}$ in year $\mathrm{t}$; Disexpt $=$ Corporate discretionary expenses $\mathrm{i}$ in year $\mathrm{t}$; At $-1=$ Total assets of the company at the end of year $\mathrm{t}-1 ; \mathrm{St}=$ Sales of the company at the end of the year Information Asymmetry in this study is measured by the average annual bidask spread (El-Mahdy and Park 2014; Bharath et al. 2008) as calculated with the following formula:

$P R E A D=($ aski, $\mathrm{t}-$ bidi, $\mathrm{t}) /\{($ aski, $\mathrm{t}+$ bidi, $\mathrm{t}) / 2\} \times 100$

where Aski,t $=$ the highest ask price of stock of company $i$ that happened on $t$ day; Bidi, $t=$ the lowest bid price of the company's stock $i$ that occurred on the day t harga ask

The quality of Internal Audit function uses measurement developed by Prawitt et al. (2009) by using scores on three indicators: auditor certification, auditor training, and audit experience owned by the auditor. The auditor certification indicator is given a score of 1 if any of the auditors hold CIA, CFE or QIA certification and is given 0 otherwise; auditor training is also given a score of 1 if the Internal Auditor is given audit training at least twice in one year and score 0 otherwise; and audit experience is given score 1 if there is a provision that to become an internal auditor must have work experience in the accounting or finance company at least 3 years and 0 otherwise. Data is collected and obtained from information disclosed in the financial statements and other information published by the Company. The calculation formula score quality internal audit function based on the proxy is given below:

$\mathrm{IAQ}_{\mathrm{it}}=\Sigma \mathrm{X}_{\mathrm{it}} / \mathrm{n}$

where IAQ = Internal Audit Quality of company $\mathrm{i}$ in year $\mathrm{t}$; Xit $=$ total scores as indicated in financial statements for company $\mathrm{i}$ in year $\mathrm{t} ; \mathrm{N}=$ Total scores: 3 . Indicators

Control variables consist of (1) leverage is measured by total debt/total asset (Ege 2015); (2) market to book value is measured with closing price/book value of shareholders equity Roychowdhury (2006); (3) firm size is measured with natural log of total assets (Dyreng et al. 2010).

\section{Research Models}

The research model is expressed in the following regression equation, namely:

Model for $\mathrm{H}_{1}$ :

$\mathrm{REM}_{i \mathrm{t}}=\beta_{0}+\beta_{2} \mathrm{INFAS}_{\mathrm{it}}+\beta_{3} \mathrm{LEV}_{\text {it }}+\beta_{4} \mathrm{SIZE}_{\mathrm{it}}+\beta_{5} \mathrm{MTB}_{\mathrm{it}}+$ 
Model for $\mathrm{H}_{2}$ :

$\mathrm{REM}_{\mathrm{it}}=\beta_{0}+\beta_{2} \mathrm{INFAS}_{\mathrm{it}}+\beta_{3} \mathrm{IAQ}_{\mathrm{it}}+\beta_{5} \mathrm{INFAS}_{\mathrm{it}}{ }^{*} \mathrm{IAQ}_{\mathrm{it}}+\beta_{6} \mathrm{LEV}_{\mathrm{it}}+\beta_{7} \mathrm{SIZE}_{\mathrm{it}}+\beta_{8} \mathrm{MTB}_{\mathrm{it}}+$

where REM $\mathrm{it}_{\mathrm{it}}$ is Real Earnings Management of company $\mathrm{i}$ in year $\mathrm{t}$ proxied wih CFO, Production Costs and Discrtionary Expenses; INFAS ${ }_{i t}$ is Information Asymmetry of company $i$ in year t; IAQ ${ }_{i t}$ is Internal Audit Quality of company i in year t; LEV is leverage; SIZE is log natural of total assets; MTB is market to book value.

\section{Data Analysis}

This study uses panel data regression model. The data are analyzed using EViews 8. Gujarati (2004) explain that in pooled estimators, the error terms are likely to be correlated over time for a given subject. Thus, if the fixed effect model is appropriate but we use the pooled estimator then the estimated coefficients will be inconsistent.

To test which model is better, Widarjono (2009) indicates the following steps, namely: Chow test, Hausman test, and Langrange Multiplier (LM) test. Chow test is to determine which model of common effect or fixed effect is used. If the Prob. cross-section $\mathrm{F}$ was smaller than $\alpha$ value $(=0.05)$ then Fixed Effect model was consistent; if it was not then common effect model is selected. Hausman test is to determine between Fixed Effect or random effect model that is suitable for regression model estimator. If the Prob. cross-section F was smaller than $\alpha$ value (=0.05) then Fixed Effect model was consistent; if it was not then Random Effect model was used. LM test is required if there were different test results between Chow test and Hausman test. For example if chow test recommended to use common effect model while Hausman test recommendeded random effect model. Then, LM test is needed to determine which model between common effect and random effect is better. LM test model is developed by Breusch and Pagan (1980). The test is based on chi-square distribusion with the degree of freedom equivalent to the amount independent variable. If LM statistic was above the critical value of chi-square then random effect is consistent; if it was not, mean otherwise.

\section{Results and Discussion}

\section{Descriptive Statistics}

Table 1 shows that market to book value and leverage have a relatively high standard deviation as compared to the mean. This indicates that sample variability for market to book value and leverage is quite high. Variable of internal audit quality has quite the same value both in average and modes; this means that each firm in the sample are homogeneous and low variability. Other control variables such as Information Asymmetry and Size have standard deviation lower than the mean. This shows that Information asymmetry and firm size is also homogeneous and low variability.

Table 1. Descriptive statistics

\begin{tabular}{lcccccc}
\hline & mean & min & max & mode & std. deviation \\
\hline Internal Audit Quality (IAQ) & 0.28 & 0 & 1.00 & 0.33 & 0.29 \\
Information Asymmetry (INFAS) & 0.54 & 0 & 0 & 0 & 0.32 \\
Leverage (LEV) & 2.70 & 0.04 & 354.99 & 0.62 & 20.11 \\
Size (SIZE) & 28.37 & 25.30 & 33.13 & 26.48 & 1.56 \\
Market To Book Value (MBV) & 84.84 & 0.05 & 7330.57 & 5.90 & 595.90 \\
\hline
\end{tabular}

Before hypothesis test, classical asumption test was undertaken. The test includes (1) data normality test; (2) heteroscedasticity test using the Glejser; (3) multicolinearity test using VIF test; and (4) autocorrelation test using Durbin-Watson Test. Data normality was tested using Eviews 8 through residual diagnostic of histogram normalitity test. The results show Skewness is in the range of 0 and Kurtosis is in the range below of 3; which mean the regression of residual is normally distributed. Other test results indicate that the data is free from autocorrelation, heteroscedasticity, and multicollinearity.

\section{The Result of Hypothesis 1}

Model selection test is conducted to decide which model is suitable for regression model estimator. Chow test and Hausman test were undertaken. Results of the test indicate for CFO and production costs regression model in table 
2 below are better to use fixed effect model, and for discretionary expenses regression is recommended to use random effect model.

Table 2 shows that information asymmetry has a positive and significant effect toward real earnings management for the pattern of cash flow from operation (CFO). Its p-value is 0.0749 (below 0.10). This means that information asymmetry has caused management to commit in real earnings management of cash flow from operation to achieve desired earnings. This findings supports Roychowdhury (2006) who explains that CFO pattern is one of the real earnings management activities which are conducted through sales manipulation.

In addition, information asymmetry has a positive and significant effect toward real earnings management for production costs pattern. Its $p$-value is below $0,05(0,0000)$. This indicates that information asymmetry motivate management to engage in real earnings management for the pattern of production costs. This result is consistent with Roychowdhury (2006); Hunton et al. (2006).

However, Information asymmetry has no effect toward real earnings management for production costs pattern. Although, $\mathrm{p}$-value is below $0,05(0,0000)$ but its coefficient has a negative direction which is not in accordance with hypothesis. This result does not support Hunton et al. (2006); Jiraporn et al. (2008) who argue that information asymmetry cause stakeholder to have inadequate resources to relevant information to monitor management activities in practice of earnings management.

The test on control variables shows that Size has a negative and significant association toward each pattern of real earnings management: Cash Flow from Operation (CFO), production costs and discretionary expenses. This suggests that a higher level of Size lead to lower real earnings management of cash flow from operation, production costs, and discretionary expense. This result supports Dechow and Dichev (2002).

Leverage consistently shows no effect toward each of the two patterns of real earnings management: CFO and production costs. Although leverage has a significant effect toward real earnings management in discretionary expenses pattern but its direction is negative; thus, it can be concluded no assocation. In contrast, previous study related to accrual earnings management demonstrated positive association (Ege 2015).

Market to book value does not affect real earnings management in the pattern of CFO and discretionary expenses. Although leverage has a significant effect toward real earnings management in CFO patterns but its direction is negative; thus, it can be concluded no assocation. This result is not consistent with study conducted by Roychowdhury (2006) who found firms with have growth opportunies tent to undertake earnings management to fulfill certain earnings thresholds.

Simultaneously, with alpha 5\%, model of the effect of information asymmetry, size, leverage, and market to book value toward real earnings management indicate a good model. This is indicated by $F$ value of 0.000 and adjusted R square valued of 0.45 for CFO pattern of real earnings management; 0.89 for production costs pattern of real earnings management; and 0.83 for discretionary expenses patten of real earnings management

Table 2. Empirical results for hypothesis 1

\begin{tabular}{|c|c|c|c|c|c|c|c|}
\hline \multicolumn{8}{|c|}{$\begin{array}{l}\text { Equation: } \\
\text { REM }_{\text {it }}=\beta_{0}+\beta_{1} \operatorname{Narcs}_{i t}+\beta_{2} \mathrm{IAS}_{\text {it }}+\beta_{3} \mathrm{LEV}_{\mathrm{it}}+\beta_{4} \mathrm{SIZE}_{\mathrm{it}}+\beta_{5} \mathrm{MTB}_{\mathrm{it}}+\end{array}$} \\
\hline \multirow[t]{2}{*}{ Variables } & \multirow[t]{2}{*}{ Pred. Sign } & \multicolumn{2}{|c|}{$\mathrm{CFO}$} & \multicolumn{2}{|c|}{ Production Costs } & \multicolumn{2}{|c|}{ Discretionary Expenses } \\
\hline & & Coeff(B) & p-value & Coeff(B) & p-value & Coeff(B) & p-value \\
\hline $\mathrm{C}$ & & 1.4733 & $0.0001 * * *$ & 3.0271 & $0.0000 * * *$ & 0.0756 & $0.0006 * * *$. \\
\hline INFAS & + & 0.0123 & $0.0749 *$ & 0.0288 & $0.0000 * * *$ & -0.0022 & $0.0000 * * *$ \\
\hline SIZE & - & -0.0521 & $0.0001 * * *$ & -0.1072 & $0.0000 * * *$ & -0.0027 & $0.0005^{* * *}$ \\
\hline LEV & + & -0.0002 & 0.1000 & 0.0007 & 0.2874 & -0.0222 & $0.0000 * * *$ \\
\hline MTBV & + & 0.6560 & 0.7050 & -0.4110 & $0.0087 * * *$ & $-0,1490$ & 0.3541 \\
\hline Adj R2 & & 0.45 & & 0.89 & & 0.83 & \\
\hline Prob (F-statistic) & & 0.0000 & $* * *$ & 0.0000 & $* * *$ & 0.0000 & $* * *$ \\
\hline $\mathrm{N}$ & & 348 & & 348 & & 348 & \\
\hline
\end{tabular}

***Significat at 1 percent; $* *$ Significant at 5 percent; *Significant at $10 \%$

Note: INFAS: Information Asymmetry; Size: natural log of total assets; LEV: Leverage; MTBV: market to book value;

\section{The Result of Hypothesis 2}

Model selection test is conducted to decide which model is suitable for regression model estimator. Chow test and Hausman test were undertaken. Results of the test indicate that for CFO and production costs regression model in table 3 are better to use fixed effect model, and for discretionary expenses regression is recommended to use random effect model.

Table 3 presents the results of internal audit quality as moderating variable for the effect of information asymmetry toward real earnings management for the patterns of CFO (Cash Flow from Operation), Production 
Costs and Discretionary Expenses. The interaction between information asymmetry and internal audit quality has a negative and significant effect toward real earnings management for the parttern of Cash Flow from Operation. The coefficient is -0.0545 ( $p$-value 0.0129 below 0.05). This shows that internal audit has significant effects in mitigating the influence of information asymmetry toward real earnings management in the pattern of Cash Flow from Operation. Cash flow from operation (CFO) is a model to show and measure whether real earnings management exists in sales activities Roychowdhury (2006). Internal auditors are involved in conducting operational audit to marketing division which the sales activities and transactions as an audit object. As a consequence, quality of internal audit has been empirically proven to have important role in reducing the impact of information asymmetry toward real earnings management practice in manipulation of cash flow from operation. This result supports Prawitt et al. (2009); Ege (2015); Gramling and Hermanson (2009).

Table 3 also demonstrates the interaction between information asymmetry and internal audit quality toward real earnings management of production costs pattern. The coefficient is 0.0881 with p-value below 0.05 (0.000). This indicates that internal audit quality has significant and positive effect in mitigating the effect of information asymmetry toward real earnings management of production cost pattern. This results support the fact that one of the internal audit roles is to perform an operational audit of the manufacuring plant (Ma'ayan and Carmeli 2016). Thus, real earnings management in production cost pattern is likely to be detected by internal auditor function quality. This result also support Prawitt et al. (2009). However, the interaction between internal audit quality and information asymmetry is not proven the internal audit quality to be the moderating variable of the relationship between information asymmetry and real earnings management of discretioanary exepenses. Altough its p-value was 0.0023 (below 0.005); however, the coefficient was positive which had opposite direction with predicted negative sign in the hypothesis. This findings indicate that internal audit quality do not play an important role in mitigating real earnings management of discretionary expenses which are related to financial statements. This result due to the role of internal audit divisions that are not involved in financial statement audits as conducted by public accounting firm, rather the internal auditors undertake safety audits, operational audits, financial audits, information security audits, risk management, survivability and disaster recovery (DRP) audits, security and forensic accounting, and management audits (Ma'ayan and Carmeli 2016).

Simultaneously, with alpha 5\%, model of the effect of Information Asymmetry, Internal Audit Quality, interaction of Information Asymmetry and Internal Audit Quality, size, leverage, and market to book value toward real earnings management indicate a good model. This is indicated by $\mathrm{F}$ value of 0.000 and adjusted $\mathrm{R}$ square valued of 0.45 for CFO pattern of real earnings management; 0.89 for production costs pattern of real earnings management; and 0.83 for discretionary expenses pattern of real earnings management.

Table 3. Empirical results for hypothesis 2

\begin{tabular}{|c|c|c|c|c|c|c|c|}
\hline \multicolumn{8}{|c|}{ 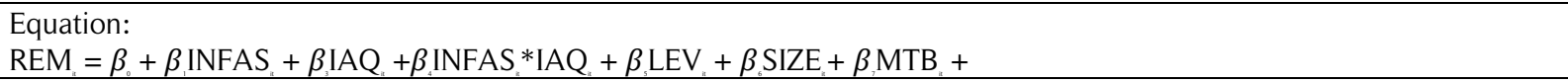 } \\
\hline \multirow[t]{2}{*}{ Variables } & \multirow[t]{2}{*}{$\begin{array}{l}\text { Pred. } \\
\text { Sign }\end{array}$} & \multicolumn{2}{|c|}{$\mathrm{CFO}$} & \multicolumn{2}{|c|}{$\begin{array}{c}\text { Production } \\
\text { Costs }\end{array}$} & \multicolumn{2}{|c|}{ Disc Expenses } \\
\hline & & Coeff (B) & $\mathrm{p}$-value & Coeff (B) & p-value & Coeff (B) & $\begin{array}{c}\mathrm{p}- \\
\text { value }\end{array}$ \\
\hline $\mathrm{C}$ & & 1.4364 & $0.0002 * * *$ & 2.6207 & $0.0000 * * *$ & -0.0410 & 0.0000 \\
\hline INFAS & + & -0.0017 & 0.8453 & 0.0046 & 0.3262 & -0.0034 & $0.0003 * * *$ \\
\hline IAQ & - & -0.0198 & 0.5886 & -0.1109 & $0.0000 * * *$ & 0.0013 & 0.7627 \\
\hline INFAS*IAQ & - & -0.0545 & $0.0129 * *$ & -0.0881 & $0.0000 * * *$ & 0.0072 & $0.0023 * * *$ \\
\hline SIZE & - & -0.0507 & $0.0002 * * *$ & -0.0917 & $0.0000 * * *$ & 0.0015 & 0.1411 \\
\hline LEV & + & -0.0002 & 0.1084 & 0.0006 & 0.3914 & 0.0267 & $0.0000 * * *$ \\
\hline MTBV & + & 0.0911 & 0.5951 & -0.0446 & $0.0006^{* * *}$ & -0.00188 & 0.3282 \\
\hline Adj R2 & & 0.45 & & 0.89 & & 0.83 & \\
\hline Prob(F-statistic) & & 0.0000 & $* * *$ & 0.0000 & $* * *$ & 0.0000 & $* * *$ \\
\hline $\mathrm{N}$ & & 348 & & 348 & & 348 & \\
\hline
\end{tabular}

***Significat at 1 percent; **Significant at 5 percent; *Significant at $10 \%$

Note: INFAS: Information Asymmetry; IAQ: Internal Audit Quality; Size: natural log of total assets; Lev: Leverage; MTBV: market to book value.

\section{Conclusion}

This study shows that information asymmetry has a positive and significant effect toward real earnings management for the pattern of cash flow from operation (CFO). This findings support Roychowdhury (2006) who expalains that CFO pattern is one of the real earnings management activities which are conducted through sales manipulation. 
This research also finds that information asymmetry is empirically proven to have positive and significant effect toward real eanings management in production cost pattern. This result is consistent with Roychowdhury (2006); Hunton et al. (2006). Meanwhile, information asymmetry has no effect toward real earnings management of production costs patter. This result does not support Hunton et al. (2006); Jiraporn et al. (2008) who argue that information asymmetry cause stakeholder to have inadequate resources to relevant information to monitor management activities in earnings management activities.

Findings related to the roles of internal audit quality have empirically proven in mitigating the influence of information asymmetry toward cash flow from operation (CFO of real earnings management. Cash flow from operation (CFO) is a model to show and measure whether real earnings management exists in sales activities (Roychowdhury 2006). Sales department is an audit object and there is a great possibility for internal auditors to detect earnings management conducted through sales activities manipulation. Therefore, management is less likely to undertake real earnings management in this pattern. This results support Prawitt et al. (2009); Ege (2015); Gramling and Hermanson (2009).

The interaction between information asymmetry and internal audit quality toward real earnings management of production costs pattern indicates that internal audit quality has significant and positive effect in mitigating the effect of information asymmetry toward real earnings management of production cost pattern. This results support the role of the internal audit which is to perform an operational audit to the manufacturing plant (Ma'ayan and Carmeli 2016). Thus, real earnings management in production cost pattern is likely to be detected by internal auditor function quality. These results also support Prawitt et al. (2009).

However, the interaction between internal audit quality and information asymmetry is not proven the internal audit quality to be the moderating variable of the relationship between information asymmetry and real earnings management of discretionary expenses. This findings indicate that internal audit quality do not play an important role in mitigating real earnings management of discretionary expenses which are related to financial statements. This result dues to the role of internal audit divisions generally focus more on non-financial statements audit (Ma'ayan and Carmeli 2016).

The results of this study contribute to the theoretical implications related to agency theory (Jensen and Meckling 1976). The results of information asymmetry that has a positive and significant effect toward real earnings management in cash flow from operation and production costs patterns support the agency problem which information asymmetry is one of the factors that motivate management to commit in real earnings management practices. This study also contributes to the literature related to the internal audit quality which has an important role in mitigating the effect of information asymmetry toward real earnings management for cashflow from operation and production costs pattern. The research has implications for shareholders which provide input that the function of internal audit quality can alleviate earnings management through real activities manipulation.

The limitation of this study is on the availability of disclosure on firm financial statements that publish internal audit quality indicators as indicated by Prawitt et al. (2009). Therefore, further study is recommended using qualitative research methods. The results would be more in-depth insight for certain internal audit quality characteristics of a firm.

\section{References}

An, Y., H. Davey, and I. R.C. Eggleton. 2011. Towards a comprehensive theoretical framework for voluntary IC disclosure. Journal of Intellectual Capital 12 (4): 571-585. https://doi.org/10.1108/14691931111181733.

Aslani, A., M. N. M. Alarlooq, and B. Azadi. 2014. Accounting conservatism impact on real earnings management. International Journal of Accounting Research 1 (12): 71-76. http://platform.almanhal.com/GoogleScholar/Details/?ID=2-63473.

Beneish, M. D., M. B. Billings, and L. D. Hodder. 2008. Internal control weaknesses and information uncertainty. Accounting Review 83 (3): 665-703. https://doi.org/10.2308/accr.2008.83.3.665.

Breusch, T. S., and A. R. Pagan. 1980. The lagrange multiplier test and its applications to model specifications in econometrics. The Review of Economic Studies 47 (1): 239-253.

Chae, C., H. Jeong, and K. Min. 2016. Dividend policy and earnings management: based on discretionary accruals and real earnings management. International Journal of U- End E- Service Science and Technology 9 (2): 137-150. https://doi.org/10.14257/ijunesst.2016.9.2.15.

Dai, Y., D. Kong, and L. Wang. 2013. Information asymmetry, mutual funds and earnings management: evidence from China. China Journal of Accounting Research 6 (3): 187-209. https://doi.org/10.1016/J.CJAR.2013.03.001. 
Dechow, P. M., and I. D. Dichev. 2002. The quality of accruals and estimation errors. The Accounting Review 77 (1): 35-59. https://doi.org/10.2308/accr.2002.77.s-1.35.

Dyreng, S. D., M. Hanlon, and E. L. Maydew. 2010. The effects of executives on corporate tax avoidance. Accounting Review 85 (4): 1163-1189. https://doi.org/10.2308/accr.2010.85.4.1163.

Ege, M. S. 2015. Does internal audit function quality deter management misconduct? The Accounting Review 90 (2): 495-527. https://doi.org/10.2308/accr-50871.

El-Mahdy, D. F., and M. S. Park. 2014. Internal control quality and information asymmetry in the secondary loan market. Review of Quantitative Finance and Accounting 43 (4): 683-720. https://doi.org/10.1007/s11156013-0389-1.

Eldenburg, L. G., K. A. Gunny, K. W. Hee, and N. Soderstrom. 2011. Earnings management using real activities: evidence from nonprofit hospitals. The Accounting Review 86 (5): 1605-1630. https://doi.org/10.2308/accr10095.

Fadzil, F. H., H. Haron, and M. Jantan. 2005. Internal auditing practices and internal control system. Managerial Auditing Journal 20 (8): 844-866. https://doi.org/10.1108/02686900510619683.

Ge, W., and J-B. Kim. 2014. Boards, takeover protection, and real earnings management. Review of Quantitative Finance and Accounting 43 (4). https://papers.ssrn.com/sol3/papers.cfm?abstract_id=2277998.

Gramling, A. A., and D. R. Hermanson. 2009. Internal audit quality: would we know it if we saw it? Internal Auditing 24 (1): 36-39.

Gujarati, D. N. 2004. Basic econometrics. New York: The McGraw-Hill. https://doi.org/10.1126/science.1186874.

Healy, P. M., and K. G. Palepu. 2001. Information asymmetry, corporate disclosure, and the capital markets: a review of the empirical disclosure literature. Journal of Accounting and Economics 31 (1-3): 405-440. https://doi.org/10.1016/S0165-4101(01)00018-0.

Hunton, J. E., R. Libby, and C. L. Mazza. 2006. Financial reporting transparency and earnings management (retracted). The Accounting Review 81 (1): 135-157. https://doi.org/10.2308/accr.2006.81.1.135.

Jafarpour, M., and S. B. Gilaniniay. 2013. Invstigate real earnings management and accounting earnings management from the perspetive of income smoothing. International Journal of Innovative Research in Science Engineering and Technology 2 (12).

Jensen, M. C., and W. H. Meckling. 1976. Theory of the firm: managerial behavior, agency costs and ownership structure. Journal of Financial Economics 3 (4): 305-360. http://ssrn.com/abstract=94043http://hupress.harvard.edu/catalog/JENTHF.html.

Jiraporn, P., G. Miller, S. S. Yoon, and Y. S. Kim. 2008. Is earnings management opportunistic or beneficial? an agency theory perspective. International Review of Financial Analysis 17: 622-634. https://papers.ssrn.com/sol3/papers.cfm?abstract_id=917941.

Jo, H., and Y. Kim. 2007. Disclosure frequency and earnings management. Journal of Financial Economics 84 (2): 561-590. https://doi.org/10.1016/J.JFINECO.2006.03.007.

Kalgo, S. H., B. A. A. Noordin, H. S. B. Nahar, and S. Z. B. Turmin. 2015. The impact of institutional investors on real and accrual earnings management around IPO: evidence from Malaysian emerging market. Capital Markets Review 23 (1\&2): 65-83.

Kassamany, T., S. Ibrahim, and S. Archbold. 2017. Accrual and real-based earnings management by UK acquirers. Journal of Accounting \& Organizational Change 13 (4): 492-519. https://doi.org/10.1108/JAOC-09-20150073.

Lang, M. H., and R. J. Lundholm. 2000. Voluntary disclosure and equity offerings: reducing information asymmetry or hyping the stock? Contemporary Accounting Research 17 (4): 623-662. https://doi.org/10.1506/9N45FOJX-AXVW-LBWJ.

Ma'ayan, Y., and A. Carmeli. 2016. Internal audits as a source of ethical behavior, efficiency, and effectiveness in work units. Journal of Business Ethics 137 (2): 347-363. https://doi.org/10.1007/s10551-015-2561-0. 
Nurcahyo, R., and A. D. Wibowo. 2015. Manufacturing capability, manufacturing strategy and performance of indonesia automotive component manufacturer. In Procedia CIRP, 26:653-657. https://doi.org/10.1016/j.procir.2014.07.046.

Olsen, K. J., and J. Stekelberg. 2016. CEO narcissism and corporate tax sheltering. The Journal of the American Taxation Association 38 (1): 1-22. https://doi.org/10.2308/atax-51251.

Prawitt, D. F., J. L. Smith, and D. A. Wood. 2009. Internal audit quality and earnings management. The Accounting Review 84 (4): 1255-1280. https://doi.org/10.2308.

Qi, B., R. Yang, and G. Tian. 2014. Can media deter management from manipulating earnings? evidence from China. Review of Quantitative Finance and Accounting 42 (3): 571-597. https://doi.org/10.1007/s11156013-0353-0.

Raoli, E. 2013. Do managers engage in earnings management to support firm's market valuation?" corporate ownership and control 10 (2 D,CONT3): 627-645.

Rizvi, W., and M. M. S. Khan. 2015. The impact of inflation on loan default : a study on Pakistan. Australian Journal of Business and Economic Studies 1 (1): 87-94.

Roychowdhury, S. 2006. Earnings management through real activities manipulation." Journal of Accounting and Economics 42 (3): 335-370. https://doi.org/10.1016/J.JACCECO.2006.01.002.

Scott, W. R. 2015. Financial accounting theory. 4thed. Canada: Person Education.

Weng, T-C., H-Y. Chi, and G.-Z. Chen. 2015. Internal control weakness and information quality. Journal of Applied Finance \& Banking 5 (5): 135-169.

Widarjono, A. 2009. Ekonometrika pengantar dan aplikasinya. Yogyakarta: Ekonisia.

$\mathrm{Xu}$, L., and A. P. Tang. 2015. Internal control material weakness, analysts accuracy and bias, and brokerage reputation. In Handbook of Financial Econometrics and Statistics, 1719-1751. https://doi.org/10.1007/978-1-4614-7750-1_63.

Zang, A. Y. 2012. Evidence on the trade-off between real activities manipulation and accrual-based earnings management. Accounting Review 87 (2): 675-703. https://doi.org/10.2308/accr-10196. 